\title{
Gross examination and Histopathology of Fibropapillomas in Chelonia mydas and Lepidochelys olivacea from Baja California Sur, Mexico
}

Eduardo Reséndiz ${ }^{1,2,3^{*}}$, Helena Fernández-Sanz $z^{2,3,4}$, Dulce Sofía Barrientos Torres ${ }^{2,3,4}$, Jorge Armando Vega-Bravo² and María Mónica Lara-Uc1,2,3

\author{
*Correspondence: jresendiz@uabcs.mx
}

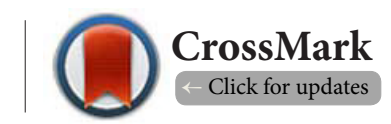

\begin{abstract}
'Departamento Académico de Ciencias Marinas y Costeras, Universidad Autónoma de Baja California Sur (UABCS). Carretera al Sur KM 5.5., Apartado Postal 19-B, C.P. 23080, La Paz B.C.S. México.

2Proyecto Salud de Tortugas Marinas - UABCS, Carretera al Sur KM 5.5., Apartado Postal 19-B, C.P. 23080, La Paz B.C.S. México.

${ }^{3}$ Alianza Keloni A.C. Antonio Rosales 698, col. Centro, C.P. 23000, La Paz B.C.S. México.

${ }^{4}$ Posgrado en Ciencias Marinas y Costeras (CIMACO) UABCS, Carretera al Sur KM 5.5., Apartado Postal 19-B, C.P. 23080, La Paz B.C.S. México.
\end{abstract}

\begin{abstract}
Background: Fibropapillomatosis (FP) is an infectious disease considered to be one of the primary causes of mortality for many green turtles stokes around the world, commonly associated with a herpesvirus identified as Chelonid herpesvirus type 5 (ChHV-5). To detect the viral particles associated with the specific lesions of FP, Histopathology, Transmission Electron Microscopy and PCR studies have been used; in this manuscript we described by gross Pathology and Histopathology cutaneous FPs in an eastern Pacific Green Turtle (EPGT) C. mydas from Ojo de Liebre lagoon (LOL) and in an olive ridley turtle L. olivacea from the Gulf of Ulloa (GU) in the Baja California Peninsula.

Methods: During September and December 2016, olive ridley turtles were caught at GU and EPGTs were caught at LOL. A physical examination adapted for sea turtles was carried out and morphometric data was taken. Two tissue samples ( 2 and $3 \mathrm{~cm}$ aprox. respectively) from two turtles that presented neoplasms were recollected; the lesions were completely resected, fixed in formalin and sent to the Marine Botany Laboratory at the Autonomous University of Baja California Sur to be processed with the Histopathology routine technique and were reviewed using a microscope with $\times 10$ and $\times 40$ lenses.

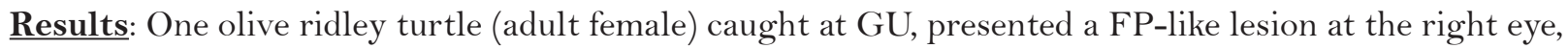
in addition to two FP-like lesions at the ventral part of the right anterior flipper; in LOL, an EPGT (sub adult female), presented a FP-like lesion at the ventral base of the right anterior flipper. The examination of the nodules by light microscopy revealed orthokeratotic hyperkeratosis, epidermal hyperplasia with areas of edema, dermal papillary differentiation, increased fibroblasts in the dermis and mild infiltration of lymphocytes arranged at the perivascular level and at the dermo-epidermal junction.

Conclusions: It is important and necessary to complement this kind of studies with the use of PCR to determine the role of the disease causative agent in the development of the neoplasms. Monitoring along the west coast of Mexico is essential to determine the presence, prevalence and incidence of FP and other diseases.
\end{abstract}

Keywords: Eastern Pacific green turtle (EPGT), black turtle, olive ridley turtle, neoplasms, fibropapillomatosis

\section{Introduction}

Sea turtles are part of multiple ecosystems in different parts of the world, being exposed to diverse environmental and anthropogenic factors that may cause them proliferative diseases

(ㄷ) 2019 Reséndiz et al; licensee Herbert Publications Ltd. This is an Open Access article distributed under the terms of Creative Commons Attribution License (http://creativecommons.org/licenses/by/3.0). This permits unrestricted use, distribution, and reproduction in any medium, provided the original work is properly cited. 
such as fibropapillomas (FP's). Cutaneous FP's are benign neoplasms, whose etiology and pathogenesis are complex due to the sea turtles life cycle and to the characteristics of the herpesvirus to which are related [1]. Fibropapillomatosis (FP) is an infectious disease considered to be one of the primary causes of mortality for many green turtle stokes around the world [2] and is commonly associated with a herpesvirus [3] identified as Chelonid herpesvirus type 5 (ChHV-5) [4]. This disease is characterized by the presence of simple to multiple benign fibroepithelial tumors [5] varying from 0.1 to $\geq 30 \mathrm{~cm}$ in diameter $[\mathbf{5 , 6 ]}$ and can present spontaneous regression [7]. Histologically, it is characterized by a papillary epidermal hyperplasia supported on broad stalks of fibrovascular stroma [8]. To detect the viral particles associated with the specific lesions of FP, Transmission Electron Microscopy (TEM) and PCR studies have been used to confirm the presence of ChHV-5 in tissues and ocular secretions of sea turtles respectively $[4,9,10]$. Tumors generally occur in the external epithelium [11] and occasionally, other type of tumors appear in internal organs [12]; there are mainly found around the eyes, including the eyelids and the conjunctiva, the soft tissue around the mouth, between the maxilla and the jaw, the neck, the base of the anterior and posterior flippers, the tail and lastly the cloaca $[13,14]$. Tumors can obstruct vision, affect floatability, generate necrosis by the pressure of the hepatic parenchyma [8], cause renal insufficiency, gastrointestinal occlusion and death by starvation due to an esophagi occlusion [15].

The effect of this disease on sea turtle population dynamics is not well understood [16]. The earliest descriptions of skin tumors identified as FPs in sea turtles date back to the 30's, beginning with a green turtle (Chelonia mydas) [17]. The prevalence and incidence of the disease increased at the 1980's [18] and since then, FP has been reported in green turtle populations around the world [19]. It has also been referenced in other sea turtle species: loggerhead turtle (Caretta caretta), olive ridley turtle (Lepidochelys olivacea), kemp'sridley turtle (Lepidochelys kempii), hawksbill turtle(Eretmochelys imbricata) $[20,21]$ and leather back turtle (Dermochelys coriacea) [22]. Some authors state that this disease develops in areas with calm water, particularly where pollutants are present due to human settlements and agricultural residues $[\mathbf{2 3}, \mathbf{2 4}]$, while others indicate that it can be confined at specific zones, like the east coast of the Big Island of Hawaii [25]. Nevertheless, in Baja California Sur (BCS), after more than 20 years of monitoring the Peninsula, there only are three reported cases of FP in sea turtles, one in a loggerhead turtle, one in an olive ridley turtle [26] and one in a green turtle [27]. Sea turtles health status and presence and dissemination of infectious diseases in BCS have been studied infrequently, so that studies of FP are just a few. In this manuscript we present the description by gross pathology and histopathology (HP) of cutaneous FP's in an eastern Pacific Green Turtle (EPGT) C. mydas from Ojo de Liebre lagoon (LOL) and in an olive ridley turtle L. olivacea from the Gulf of Ulloa (GU) in the Baja California Peninsula.

\section{Methods}

During routine monitoring between September and December 2016, olive ridley turtles were caught by hand (Rodeo) in the GU and EPGTs were caught by net lying at LOL. A physical examination adapted for sea turtles was carried out following the methodology proposed in [28] and morphometric data was taken following the methodology described in [29]. Two tissue samples ( 2 and $3 \mathrm{~cm}$ aprox. respectively) were recollected by infiltrating $3 \mathrm{ml}$ of anesthesia (epinephrine + procaine (Adrecaine ${ }^{\circledR}$ Laboratorios Aranda S.A de C.V. Reg. SAGARPA Q-0449-093)) subcutaneously divided into five points around the base of the neoplasms. After the application of the anesthesia (1 min approx.), the base of the tumors was clamped with hemostasis clamps and the tissues were incised with a scalpel knife. The lesions were completely resected and were placed in a $25 \mathrm{ml}$ plastic sterile flask fixed by immersion in $10 \%$ buffered formalin $(7.4 \mathrm{pH})$. The EPGT in LOL was tagged with metal tags monel 400 /inconel 625 in the rear flippers following the methodology described in [30] before releasing it. The samples were sent to the Marine Botany Laboratory in the UABCS where were processed using the HP routine technique [31] to be reviewed using a microscope Olympus ${ }^{\oplus}$ CX31 with $\times 10$ and $\times 40$ lenses.

\section{Results}

On October $21^{\text {st }} 2016$, a total of 10 sea turtles, 8 loggerhead and 2 olive ridley turtles, were caught by rodeo at GU (Lat: 25.1816111 Long:-112.4285833). Among them, one olive ridley turtle presented a FP-like lesion at the right eye, in addition to two FP-like lesions at the ventral part of the right anterior flipper. The organism measured $70.5 \mathrm{~cm}$ of CCL (Curved Carapace Length) and weighed $35 \mathrm{~kg}$; according to its anatomical and morphological characteristics it was consider an adult female (Table 1). During the physical examination, a nodule of approximately $1 \mathrm{~cm}$ in diameter was observed at the lateral canthus of the cornea in the right eye, firm in consistency, pale pink colored and with semicircular morphology (Figure 1). On the proximal ventral surface of the right anterior flipper, two verrucous nodules of approximately $2-4 \mathrm{~cm}$ in diameter were observed; they were firm in consistency, rough in appearance and pale pink and yellow colored (Figure 2).

Table 1. General information of the captured sea turtles.

\begin{tabular}{llllllll}
\hline ID & Date & Sp. & Tags & CCL & Weight & Age class & Sex \\
\hline T42mar & 21oct16 & Lo & - & 70.5 & 35 & Adult & F \\
T33lol & 08nov16 & Cm & R: 1AS038 & 75.6 & 37 & Sub adult & F \\
& & & L: 1AS039 & & & & \\
\hline
\end{tabular}

${ }^{\star}$ ID: Identification; Sp: Species; Lo: Lepidochelys olivacea; $\mathrm{Cm}$ : Chelonia mydas; $R$ : Right flipper, $L$ : Left flipper; CCL: Curve Carapace Length; F: Female.

On November $8^{\text {th }} 2016,4$ EPGTs were captured in "El Datil" (Lat: 27.7737778 Long:-114.1725833) at LOL; one of them presented a FP-like lesion at the ventral base of the right anterior 


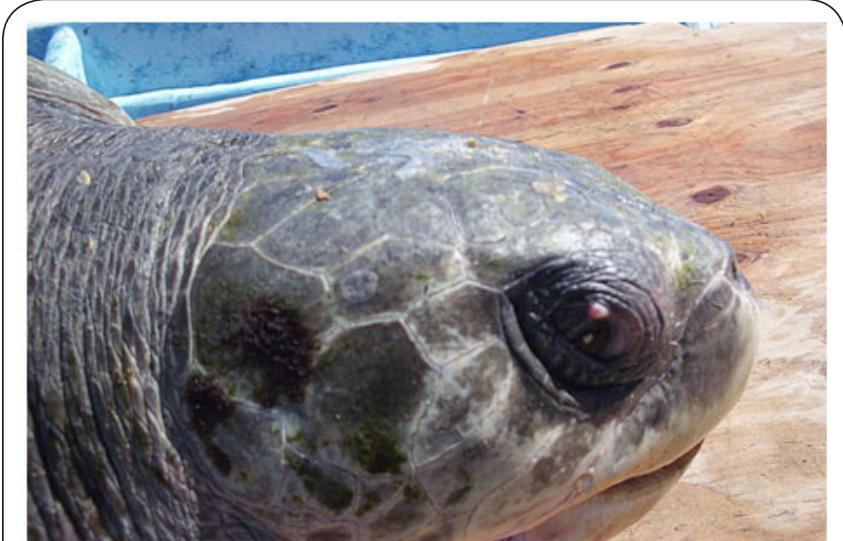

Figure 1. Nodule of approximately $1 \mathrm{~cm}$ in diameter on the lateral cornea canthus of the right eye of an olive ridley turtle in GU, firm in consistency, pale pink colored and with semicircular morphology.

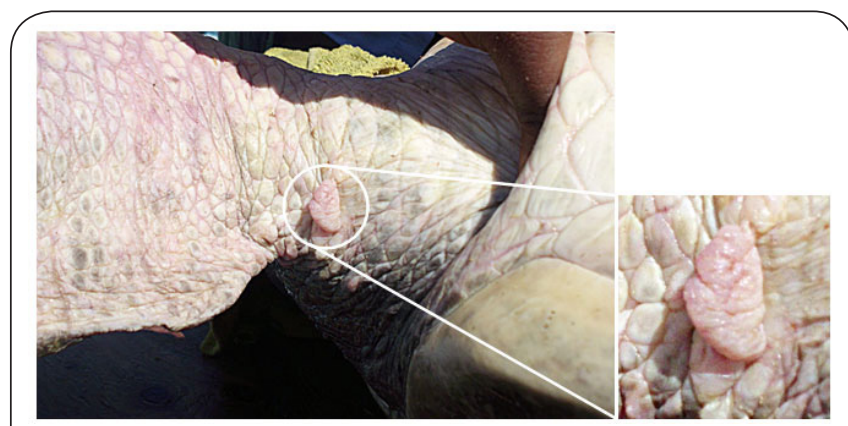

Figure 2. Verrucous nodules of approximately $2-4 \mathrm{~cm}$ in diameter on the proximal ventral surface of the right anterior flipper of an olive ridley turtle in GU, firm in consistency, rough in appearance and palepink, gray and yellow colored.

flipper. The EPGT was considered a sub adult female according to its anatomical and morphological characteristics and its biometrics, CCL: $75.6 \mathrm{~cm}$ and weight: $37 \mathrm{~kg}$ (Table 1). During the physical examination, a $3 \times 3 \mathrm{~cm}$ verrucous nodulation was observed at the ventral base of the right anterior flipper, this nodule was firm in consistency and pale pink and white colored (Figure 3).

The examination of the nodules by light microscopy revealed orthokeratotic hyperkeratosis, epidermal hyperplasia with areas of edema, dermal papillary differentiation, increased fibroblasts in the dermis and mild infiltration of lymphocytes arranged at the perivascular level and at the dermo-epidermal junction (Figures 4 and 5 ).

\section{Discussion}

Previously, characteristic signs of FP (fibroepithelial tumors around the eyes and at the base of the flippers with cauliflowerlike morphology and verrucous appearance) were recorded in juvenile, adult female and adult male sea turtles $[1,18,23,32]$.

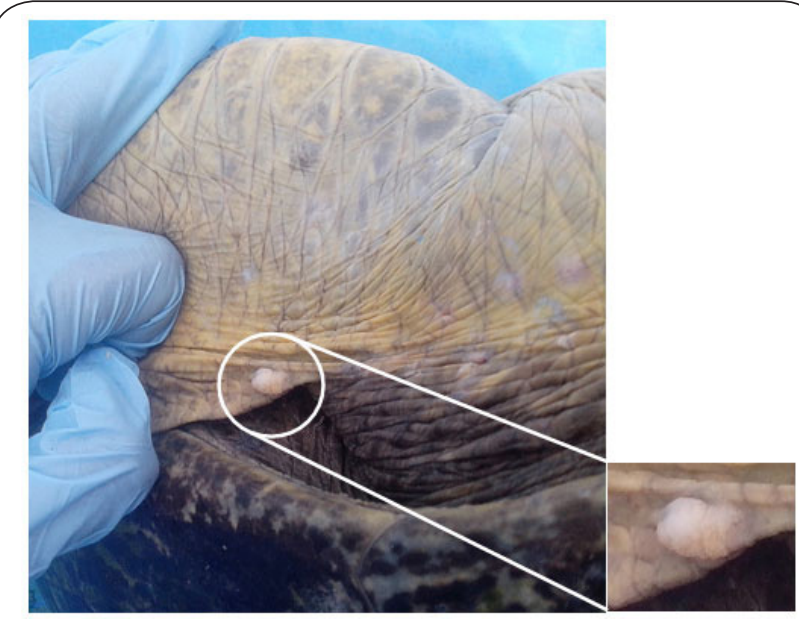

Figure 3. Ventral base of the right anterior flipper of an EPGT. A $3 \times 3 \mathrm{~cm}$ verrucous nodulation is observed, firm in consistency to the touch and pale pink and yellow with white colored.

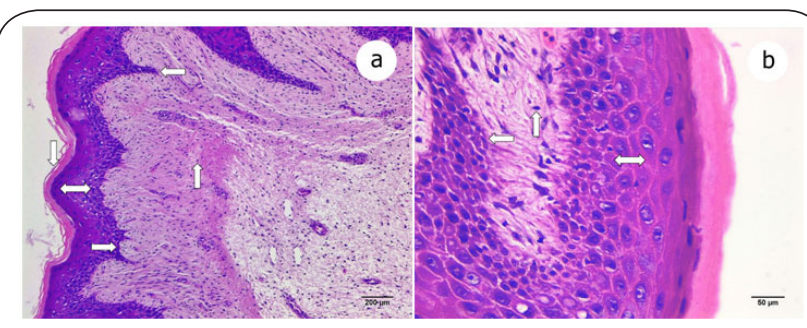

Figure 4. Olive ridley turtle cutaneous FP.

a)Hyperkeratosis $(\downarrow)$, epidermal hyperplasia $(\Leftrightarrow)$, acanthosis $(\Rightarrow)$, papilla formation $(\Leftarrow)$ and proliferation of fibroblasts in dermis $(\Uparrow)$. (10x magnification with hematoxylin and eosin stain; scale bar $=200 \mu \mathrm{m})$.

b) Epidermal hyperplasia $(\Leftrightarrow)$, papilla formation $(\Leftarrow)$ and proliferation of fibroblasts in the dermis $(\Uparrow)$. (40x magnification with hematoxylin and eosin stain; scale bar $=$ $50 \mu \mathrm{m})$.

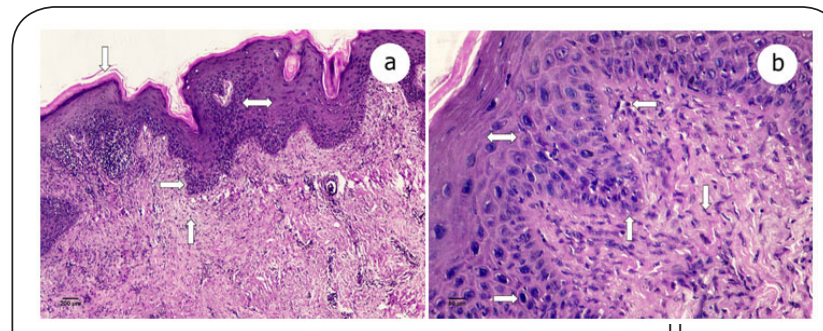

Figure 5. EPGT cutaneous FP. a) Hyperkeratosis $(\downarrow)$, Epidermal hyperplasia $(\Leftrightarrow)$, acanthosis $(\Rightarrow)$ and fibroblast proliferation in dermis $(\Leftarrow)$. ( $10 \times$ magnification with hematoxylin and eosin stain; scale bar $=200 \mu \mathrm{m})$. b) Epidermal Hyperplasia $(\Uparrow)$ with ballooning degeneration in cells $(\Leftrightarrow)$, dermal papillary differentiation $(\Leftarrow)$, increased fibroblasts in the dermis $(\downarrow)$ and mild infiltration of lymphocytes arranged at the perivascular level and at the dermo-epidermal junction $(\Leftarrow)$. ( $40 \times$ magnification with hematoxylin and eosin stain; scale bar $=50 \mu \mathrm{m})$. 
However, it has been reported that the incidence of these signs is higher in females [25], possibly due to differences in behavioral ecology and sociability of these organisms during their life cycle [33]. Several authors suggest a possible infection of organisms in common nesting, feeding and neritic development sites $[\mathbf{8 , 4}, \mathbf{2 5}, \mathbf{3 4}]$ as higher densities of turtles favor direct contact between diseased individuals, carrier organisms and those who may be susceptible [9]. In such aggregations, FP has been related to the presence of sea leeches, particularly Ozobranchus margoi and other ectoparasites considered vectors [35]. However, other authors indicate that ChHV-5 can be present in turtles without clinical manifestation and without leeches, which limits the study of the possible relationships of FP among the different species of sea turtles [36]. Additionally, there is evidence for hypotheses that ChHV-5 is a near ubiquitous virus with latency characteristics that requires one or more possibly environmental or immune related cofactors to induce $\mathrm{FP}$, so that, clinically healthy sea turtles from different sites where FP has not been reported yet across species can carry ChHV-5 DNA [37]. ChHV-5 has been associated as a primary etiological agent of FP based on three lines of evidence. First of all, when the tumors analyzed by PCR produce sequences of ChHV-5 [38]; second, when tumors occasionally exhibit epidermal viral inclusions with ultrastructures similar to those of herpes-like viruses [39]; and lastly, the experimental transmission of the disease using tumor extracts inoculated in healthy turtles that has resulted in the development of disease (FP) $[\mathbf{8}, \mathbf{1 1}]$. Nevertheless, the etiology, pathogenesis and epidemiology of ChHV-5 as a causal agent for FP remains unfinished, as defined in Koch's four postulates which establish relationships to identify the causal agent of a disease, in addition to other factors that complicate its study and limit the demonstration of its true participation in the development of neoplasms [38].

In Mexico, there have been reports of FP with clinical manifestation affecting olive ridley turtles in Colima and Oaxaca $[40,41]$. In BCS, at the GU two cases of FP with and without clinical manifestation were described in 2014 in an olive ridley turtle and a loggerhead turtle respectively [26]; in 2016, lesions of FP in a green turtle were described macroscopically and microscopically and identifying viral particles by TEM [27].

External morphology and distribution of the observed neoplasms were consistent with previous descriptions of FP in green turtles [35]. The histopathological analysis revealed that the characteristics and proliferative changes observed in the skin lesions were similar to FP associated with viral particles [27], possibly a herpesvirus [11]; these proliferative changes indicates that are benign neoplasms. However, in this case the lesions could not be monitored to specify its change on size, preventing us to specify the stage of development of the FP [6] or if it was in phase of tumor regression [7]; even so, the neoplasms were registered as 1 (less than $5 \mathrm{~cm}$ ), according to the classification of green turtles FP's proposed in $[6,42]$ and the classification of olive ridley turtles FP's proposed in [41].
These cases are the fourth and fifth (respectively) recorded and studied by HP in the peninsula, but the first in an EPGT at $\mathrm{LOL}$ and the second in an olive ridley turtle at the GU. The classification of FP presents differences in each region, so it is necessary to categorize its presence in sea turtles in the area. This can also be easily adjusted for a better comprehension of the regional differences in FP manifestation, whilst maintaining a consistent standardized data collection to allow comparisons of different geographic regions [42].

It is important and necessary to complement this kind of studies with the use of $P C R$, since it has been documented that FP in sea turtles is associated with ChHV-5 [9]. Herpesviruses are numbered according to the sequence of their detection; number 5 in ChHV- 5 indicates that there are four other Chelonid herpesviruses [4]; in this case it was not possible to determine the presence of ChHV-5 or its participation in the development of the neoplasms. However, it is important to continue with this kind of studies since the presence of ChHV-5 can pose as a serious threat to different segments of the population of sea turtles that frequent the area.

FP has a higher prevalence in near-shore habitats with poor water exchange (lagoons, bays, etc.) like LOL, and in areas that are impacted by human activities and urban development, suggesting that environmental degradation may play a significant role in the disease expression [43-45]. Consequently, the incidence of FP in sea turtles may prove to be a prime indicator of ecosystem health [46]. The variation in water temperatures in the shallow LOL and GU could affect the rate of FP's proliferation, pathogen, replication, immune system function, and/or toxin metabolism. Some studies indicate that tumors grow faster in summer with warmer water temperatures, while others report they reduce during autumn when the water cools; the onset of colder water temperatures in winter may cause further stress on FP affected turtles, enough to cause the winter stranding peak $[33,47]$. Besides, reports indicate that FP manifestation occurs after the turtles visit feeding areas and coastal foraging pastures $[4,45]$ like $G U$ and LOL, where high population densities of vectors or intermediate host species could enhance the disease transmission. Aggregation of turtles from many different breeding stocks into these common feeding areas may allow the exchange of many diseases, including FP $[2,24]$.

\section{Conclusion}

FP requires close monitoring along the west coast of Mexico. Monitoring sea turtles in foraging areas should be intensified to obtain reliable data to help us understanding the etiology, progression and regression of the disease in relation to the life history of sea turtles; it is necessary to monitor the environmental and anthropogenic factors that support the spreading of FP.

Research lines should work with specialists in pathology, immunology and epidemiology to determine the presence, prevalence and incidence of FP and other diseases. 
Threats that pose as health risks to other sea turtle species should also be studied by specialists in GU and LOL, which are regions with a high conservation value.

This information will help to complement the organisms and ecosystem management plans as well as to generate conservation strategies together with local authorities.

\section{Competing interests}

The authors declare that they have no competing interests.

\section{Authors' contributions}

\begin{tabular}{|l|c|c|c|c|c|}
\hline Authors' contributions & ER & HF & DSB & JAV & MML \\
\hline Research concept and design & $\checkmark$ & -- & -- & -- & $\checkmark$ \\
\hline Collection and/or assembly of data & $\checkmark$ & $\checkmark$ & $\checkmark$ & $\checkmark$ & -- \\
\hline Data analysis and interpretation & $\checkmark$ & $\checkmark$ & $\checkmark$ & $\checkmark$ & -- \\
\hline Writing the article & $\checkmark$ & $\checkmark$ & $\checkmark$ & $\checkmark$ & -- \\
\hline Critical revision of the article & $\checkmark$ & $\checkmark$ & $\checkmark$ & $\checkmark$ & $\checkmark$ \\
\hline Final approval of article & $\checkmark$ & $\checkmark$ & $\checkmark$ & $\checkmark$ & $\checkmark$ \\
\hline Statistical analysis & -- & -- & -- & -- & -- \\
\hline
\end{tabular}

\section{Acknowledgements}

We thank Proyectos PROCER 2016"Participación Social en el Monitoreo del Hábitat Crítico de la Tortuga Negra en La Laguna Ojo de Liebre y la Laguna de San Ignacio"(OFICIO.- E.No. F00. DRPBCPN/700/2016) and "Condición y Distribución de las tortugas marinas del Golfo de Ulloa y Playa San Lázaro BCS" (OFICIO. E.No.F00.DRPBCPN/696/2016) from Programa de Conservación de Especies en Riesgo (PROCER) of the Comisión Nacional de Áreas Naturales Protegidas (CONANP), for funding this research and for their assistance during fieldwork. We also thank Everardo Mariano Meléndez and Oscar Javier Salazar Méndez (Reserva de la Biosfera el Vizcaíno) for their support and guidance during this research, Noé López-Paz, Gabriel "Nan" Zaragoza, Jesús Porras, Alejandro Malagamba, Rafael Buelna Grado, for their assistance and fieldwork support. In addition, Aarón Sánchez Castillo, Fabián Castillo-Romero, Joaquín Rivera Rodríguez, Antonio Zaragoza from Exportadora de Sal S.A. (ESSA), who collaborated with logistics and fieldwork. Also Thanks to Yoalli Hernández Gill and Ana Sofía Merino-Zavala from the UABCS for their help during fieldwork. Finally, thanks to Captains Fernándo Romero Romero and Aarón Romero Romero from puerto Adolfo López Mateos and Miguel Angel Ramírez Mercado, Daniel Porras and Rogelio Ojeda Piementel from Procuraduria Federal de Protección al Ambiente (PROFEPA - SEMARNAT) for their assistance and fieldwork support. This research was conducted with the permits: SGPA/ DGVS/05533/16 and SGPA/DGVS/07915/16.

\section{Publication history}

Editor: Giuseppe Musumeci, University of Catania, Italy. Received: 20-Nov-2018 Final Revised: 14-Dec-2018 Accepted: 17-Dec-2018 Published: 05-Jan-2019

\section{References}

1. Aguirre AA, Balazs GH, Zimmerman B and Spraker TR. Evaluation of Hawaiian green turtles (Chelonia mydas) for potential pathogens associated with fibropapillomas. J Wildl Dis. 1994; 30:8-15. | Article | PubMed

2. Herbst L. Fibropapillomatosis of marine turtles. Annu Rev Fish Dis. 1994; 4:389-425.
3. Page-Karjian, Norton AT, Ritchie B, Brown C, Mancia C, JackwoodM and Gottdenker N. Quantifying chelonidherpes virus 5 in symptomatic and asymptomatic rehabilitating Green sea turtles.Endangered Species Res. 2015; 28:135-146.

4. Ene A, Su M, Lemaire S, Rose C, Schaff S, Moretti R, Lenz J and Herbst LH. Distribution of chelonid fibropapillomatosis-associated herpesvirus variants in Florida: molecular genetic evidence for infection of turtles following recruitment to neritic developmental habitats. J Wildl Dis. 2005; 41:489-97. | Article | PubMed

5. Aguirre A, Spraker T, Chaves A, Toit L, Eure W and Balazs G. Pathology of fibropapillomatosis in olive ridley turtles Lepidochelys olivacea nesting in Costa Rica. J AquatAnim Health. 1999; 11:283-289. | Article

6. Work TM and Balazs GH. Relating tumor score to hematology in green turtles with fibropapillomatosis in Hawaii. J Wildl Dis. 1999; 35:804-7. I Article I PubMed

7. Machado Guimaraes S, Mas Gitirana H, Vidal Wanderley A, MonteiroNeto $C$ and Lobo-Hajdu G. Evidence of regression of fibropapillomas in juvenile green turtles Chelonia mydas caught in Niteroi, southeast Brazil. Dis Aquat Organ. 2013; 102:243-7. | Article I PubMed

8. Herbst L, Jacobson LE, Moretti R, Brown T, Sundberg J and Klein P. Experimental transmission of green turtle fibropapillomatosis using cell-free tumor extracts. Dis Aquat Org. 1995; 22:1-12. | Pdf

9. Work TM, Dagenais J, Balazs GH, Schettle N and Ackermann M. Dynamics of Virus Shedding and In Situ Confirmation of Chelonid Herpesvirus 5 in Hawaiian Green Turtles With Fibropapillomatosis. Vet Pathol. 2015; 52:1195-201. | Article | PubMed

10. Page-Karjian A, Gottdenker NL, Whitfield J, Herbst L, Norton TM and Ritchie B. Potential Noncutaneous Sites of Chelonid Herpesvirus 5 Persistence and Shedding in Green Sea Turtles Chelonia mydas. J Aquat Anim Health. 2017; 29:136-142. | Article | PubMed

11. Herbst LH, Jacobson ER, Klein PA, Balazs GH, Moretti R, Brown T and Sundberg JP. Comparative pathology and pathogenesis of spontaneous and experimentally induced fibropapillomas of green turtles (Chelonia mydas). Vet Pathol. 1999; 36:551-64. | Article | PubMed

12. Jacobson E,Mansell J,Sundberg J,Hajjar L, Reichmann M, Ehrhart L, Walsh $\mathrm{M}$ and Murru F. Cutaneous fibropapillomas of green turtles (Chelonia mydas). J Comp Pathol. 1989; 101:39-52. | Article

13. Brooks DE, Ginn PE, Miller TR, Bramson L and Jacobson ER. Ocular fibropapillomas of green turtles (Chelonia mydas). Vet Pathol. 1994; 31:335-9. | Article | PubMed

14. Work TM, Balazs GH, Rameyer RA and Morris RA. Retrospective pathology survey of green turtles Chelonia mydas with fibropapillomatosis in the Hawaiian Islands, 1993--2003. Dis Aquat Organ. 2004; 62:163-76. | Article | PubMed

15. Work TM, Rameyer RA, Balazs GH, Cray C and Chang SP. Immune status of free-ranging green turtles with fibropapillomatosis from Hawaii. $J$ Wildl Dis. 2001; 37:574-81. | Article | PubMed

16. Aguirre AA, Spraker TR, Balazs GH and Zimmerman B. Spirorchidiasis and fibropapillomatosis in green turtles from the Hawaiian Islands. J Wildl Dis. 1998; 34:91-8. | Article | PubMed

17. Smith GM and Coates CW. Fibro-epithelial growths of the marine turtles Chelonia mydas (L.). Zool (New York). 1938; 23:93-98.

18. Balazs G, Aguirre A and Murakawa S. Occurrence of oral fibropapillomas in the Hawaiian green turtle: differential disease expression. Mar Turt News. 1997; 76:1-4.

19. Work TM, Dagenais J, Balazs GH, Schumacher J, Lewis TD, Leong JA, Casey RN and Casey JW. In vitro biology of fibropapilloma-associated turtle herpesvirus and host cells in Hawaiian green turtles (Chelonia mydas). J Gen Virol. 2009; 90:1943-50. | Article | PubMed

20. Balazs $\mathrm{G}$ and Jacobson $\mathrm{E}$. Health advisory for fibropapilloma disease. Mar Turt News. 1990; 49:27.

21. Greenblatt RJ, Work TM, Dutton P, Sutton CA, Spraker TR, Casey RN, Diez $\mathrm{CE}$, Parker D, St Leger J, Balazs GH and Casey JW. Geographic variation in marine turtle fibropapillomatosis. J Zoo Wildl Med. 2005; 36:527-30. | Article I PubMed

22. Huerta P, Pineda H, Aguirre A, Spraker T, Sarti L and Barragán A. First 
Reséndiz et al. Journal of Histology \& Histopathology 2019,

Confirmed Case of Fibropapilloma in a Leatherback Turtle (Dermochelys coriacea). In Proceedings of the 20th annual symposium on sea turtle biology and conservation (Vol. 193).US Department of Commerce, NOAA Technical Memorandum NMFS-SESFC-477.

23. Aguirre A,Balazs G, Spraker T and Gross T. Adrenal and hematological responses to stress in juvenile green turtles (Chelonia mydas) with and without fibropapillomas. PhysiolZool. 1995; 68:831-854. | Article

24. Herbst LH and Klein PA. Green turtle fibropapillomatosis: challenges to assessing the role of environmental cofactors. Environ Health Perspect. 1995; 103 Suppl 4:27-30. | Article | PubMed Abstract | PubMed FullText

25. Work TM, Balazs GH, Wolcott M and Morris R. Bacteraemia in free-ranging Hawaiian green turtles Chelonia mydas with fibropapillomatosis. Dis Aquat Organ. 2003; 53:41-6. | Article | PubMed

26. Cordero-Tapia A, Reséndiz Morales E. Reporte Médico y Forense de la Tortuga Amarilla (Caretta caretta) en Bahía de Ulloa B.C.S. México. Informe final de investigación. Proyecto: Estudio Sobre las Causas de Muerte de la Tortuga Amarilla (Caretta Caretta) en laCosta Occidental de Baja California Sur (Golfo De Ulloa). Comisión Nacional de Áreas Naturales Protegidas, Universidad Autónoma de Baja California Sur, Centro interdisciplinario de Ciencias Marinas del IPN, Centro de Investigaciones Biológicas del Noroeste. 2014; 115:122-195.

27. Resendiz E, Flores-Ramirez S, Koch V and Cordero-Tapia A. First Record of Fibropapillomatosis in a Green Turtle Chelonia mydas from the Baja California Peninsula. J Aquat Anim Health. 2016; 28:252-257. | Article | PubMed

28. Valdivia PA, Zenteno-Savin T, Gardner SC and Aguirre AA. Basic oxidative stress metabolites in eastern Pacific green turtles (Chelonia mydas agassizii). Comp Biochem Physiol C Toxicol Pharmacol. 2007; 146:111-7. I Article | PubMed

29. Bolten A. Techniques for measuring sea turtles. In Eckert $K$, Bjorndal $K$, Abreu- Grobois A and Donnelly M (Eds.), Research and Management Techniques for the Conservation of Sea Turtles1999. IUCN/SSC Marine TurtleSpecialistGroupPublication No. 4.

30. Balazs G. Factores a Considerar en el Marcado de Tortugas Marinas. In Eckert K, Bjorndal K, Abreu- Grobois A and Donnelly M (Eds.), Técnicas de Investigación y Manejo para la Conservación de las Tortugas Marinas. GrupoEspecialista en Tortugas Marinas 1999. UICN/CSE Publicación No. 4.

31. Bancroft J and Stevens A. Theory and practice of histological techniques, 2nd edition. In Edinburgh; New York: Churchill Livingstone. 1982; 662.

32. Aguirre $A$ and Balazs $G$. Blood biochemistry values of green turtles, Chelonia mydas, with and without fibropapillomatosis. Comp Haematollnt. 2000; 10:132-137. | Article

33. Arthur K, Limpus C,Balazs G, Capper A,Udy J, Shaw G,Keuper-Bennett $U$ and Bennett $P$. The exposure of green turtles (Cheloniamydas) to tumour promoting compounds produced by the cyanobacterium Lyngbya majuscula and their potential role in the aetiology of fibropapillomatosis. Harmful Algae. 2008; 7:114-125. | Article

34. Flint M, Limpus CJ, Patterson-Kane JC, Murray PJ and Mills PC. Corneal fibropapillomatosis in green sea turtles (Chelonia mydas) in Australia. J Comp Pathol. 2010; 142:341-6. | Article | PubMed

35. Greenblatt RJ, Work TM, Balazs GH, Sutton CA, Casey RN and Casey JW. The Ozobranchus leech is a candidate mechanical vector for the fibropapilloma-associated turtle herpesvirus found latently infecting skin tumors on Hawaiian green turtles (Chelonia mydas). Virology. 2004; 321:101-10. | Article | PubMed

36. Alfaro-Nunez A, Frost Bertelsen M, Bojesen AM, Rasmussen I, ZepedaMendoza L, Tange Olsen M and Gilbert MT. Global distribution of Chelonid fibropapilloma-associated herpesvirus among clinically healthy sea turtles. BMC Evol Biol. 2014; 14:206. | Article | PubMed Abstract | PubMed FullText

37. Alfaro-Nunez A, Bojesen AM, Bertelsen MF, Wales N, Balazs GH and Gilbert MT. Further evidence of Chelonid herpesvirus 5 (ChHV5) latency: high levels of ChHV5 DNA detected in clinically healthy marine turtles. PeerJ. 2016; 4:e2274. | Article | PubMed Abstract | PubMed FullText

38. Alfaro-Nunez A and Gilbert MT. Validation of a sensitive PCR assay for the detection of Chelonid fibropapilloma-associated herpesvirus in latent turtle infections. J Virol Methods. 2014; 206:38-41. | Article | PubMed

39. Jacobson E,Buergelt C, Williams B and Harris R. Herpesvirus in cutaneous fibropapillomas of the green turtle Chelonia mydas. DisAquatOrg. 1992; 12:1-6.

40. Gámez S, García J, Osorio D, Vázquez L and Constantino F. Patología de las tortugas marinas (Lepidochelys olivacea) que arribaron a las playas de Cuyutlán, Colima, México. VetMéxico. 2009; 40:69-78. | Article

41. Reséndiz E, Cedillo-Peláez C, Harfush M, Salas-Garrido G and Constantino-Casas F. Caracterización macroscópica, microscópica, y ultraestructural de fibropapilomas de tortugas golfina (Lepidochelys olivacea) de playa "Escobilla" Oaxaca.[Macroscopic, microscopic, and ultrastructural characterization of fibropapillomas in olive ridley turtles at Escobilla Beach, Oaxaca.]. Ciencia y Mar. 2015; 24:3-18.

42. Rossi S, Sanchez-Sarmiento AM, Vanstreels RE, Dos Santos RG, Prioste $\mathrm{FE}$, Gattamorta MA, Grisi-Filho JH and Matushima ER. Challenges in Evaluating the Severity of Fibropapillomatosis: A Proposal for Objective Index and Score System for Green Sea Turtles (Chelonia mydas) in Brazil. PLoS One. 2016; 11:e0167632. | Article | PubMed Abstract | PubMed FullText

43. Daszak $P$, Cunningham $A A$ and Hyatt $A D$. Emerging infectious diseases of wildlife-threats to biodiversity and human health. Science. 2000; 287:443-9. | Article | PubMed

44. Plowright RK, Sokolow SH, Gorman ME, Daszak P and Foley JE. Causal inference in disease ecology: investigating ecological drivers of disease emergence. Front Ecol Environ. 2008; 6:420-429. | Article

45. Stringell TB, Clerveaux WV, Godley BJ, Phillips Q, Ranger S, Richardson $P B$, Sanghera A and Broderick AC. Fisher choice may increase prevalence of green turtle fibropapillomatosis disease. Front Mar Sci. 2015; 2:57. | Article

46. Aguirre AA and Lutz PL. Marine turtles as sentinels of ecosystem health: is fibropapillomatosis an indicator? EcoHealth. 2015; 1:275-283. | Article

47. Van Houtan KS, Smith CM, Dailer ML and Kawachi M. Eutrophication and the dietary promotion of sea turtle tumors. PeerJ. 2014; 2:e602. I Article | PubMed Abstract | PubMed FullText

\section{Citation:}

Reséndiz E, Fernández-Sanz H, Torres DSB, VegaBravo JA and Lara-Uc MM. Gross examination and Histopathology of Fibropapillomas in Chelonia mydas and Lepidochelys olivacea from Baja California Sur, Mexico. J Histol Histopathol. 2019; 6:1. http://dx.doi.org/10.7243/2055-091X-6-1 